\title{
Business Continuity Management for Organizational Success: Definitions, Triggers, and Key Processes.
}

\author{
Yahya Ahmed \\ Computer Science Department \\ Federal College of Education, Yola \\ ahmedyahya@fceyola.edu.ng \\ Phone: +2347066337322
}

\section{ABSTRACT}

This paper discusses the need for business continuity management and its relevance to the successful management, protection, and sustainability of businesses. Considering the dynamic nature of global events and how it affects businesses at the speed of light. The rapid growth in technological innovations has made the world a global village, where business processes are done within the shortest time possible. This has made inter-organizational linkage and dependence very easy. But there is a need for protection against any form of disruptions for business continuity. Taking into consideration the scarce resources that lead to violence and terrorism from one place to another for power and resources. The paper look into business continuity, business continuity management, the impact of not having business continuity management, the triggers of business continuity management and the procedure for effective business continuity management.

Keywords: Business Continuity, Management, Organizational Success, Triggers, Key Processes.

Proceedings Reference Format

Yahya Ahmed (2021) Business Continuity Management for Organizational Success: Definitions, Triggers, and Key Processes. Proceedings of the 27th iSTEAMS Multidisciplinary Innovations \& Technology Transfer (MINTT) Conference. Academic City University College, Accra, Ghana. June, 2021. Pp 432 https://doi.org/ 10.22624/AIMS/iSTEAMS-2021/V27P43 